\title{
EDUVITAL: IFJÚSÁGI EGÉSZSÉGTUDATOSSÁGI ÉS NEVELÉSI PROGRAM
}

\section{EDUVITAL: HEALTH CONSCIOUSNESS AND EDUCATION PROGRAM FOR YOUTH}

\author{
Nagyné Horváth Emília', Feith Helga', Falus András (levelező szerző) \\ 'pedagógus, Kőbányai Bem József Általános Iskola, Budapest \\ hemike51@gmail.com \\ ²tanszékvezető főiskolai tanár, Semmelweis Egyetem Egészségtudományi Kar Társadalomtudományi Tanszék, Budapest \\ h.feith@se-etk.hu \\ ${ }_{3}^{3}$ professor emeritus, Semmelweis Egyetem Általános Orvostudományi Kar Genetikai, Sejt- és Immunbiológiai Intézet, Budapest \\ falus.andras@med.semmelweis-univ.hu
}

\begin{abstract}
ÖSSZEFOGLALÁS
2012. január óta működik az EDUVITAL Nonprofit Egészségnevelési Társaság. A szerveződés szakértői csapata az egészségre (= EGÉSZ-SÉG) vonatkozó sokoldalú oktatási-nevelési programokat kutat és fejleszt, elsősorban az ifjúságra közvetlenül ható szakemberek (pedagógusok, pszichológusok, háziorvosok, szociológusok, védőnők, lelkipásztorok, szociális munkások), szülők és fiatalok számára. A nonprofit szervezetet néhai Kopp Mária és Falus András alapították. Az EDUVITAL eddigi legnagyobb vállalkozása az MTA által támogatott négyéves Egészségnevelés kortársoktatással (TANTUdSZ) kutatási pályázata, mely jelenleg félidejénél tart.
\end{abstract}

\section{ABSTRACT}

The EDUVITAL Nonprofit Healthcare Company has been operating since January 2012. The team of experts in EDUVITAL examine and develop versatile educational programs for health care. Specially educated professionals (teachers, psychologists, general practitioners, sociologists, tutors, pastors, and social workers), parents and children are involved in the activity of EDUVITAL. The nonprofit organization was founded by the late Mária Kopp and András Falus. EDUVITAL's largest venture is the four-year long research program for health education (TANTUdSZ) supported by the Hungarian Academy of Sciences, which is currently in the mid-term.

Kulcsszavak: egészségtudatosság, epigenetika, életmód, komplex egészségnevelés

Keywords: health consciousness, epigenetics, healthy lifestyle, complex health education 


\section{BEVEZETÉS}

„Az egészséges népesség a társadalmi célok elérésének kulcstényezője” (Gilbert et al., 2010). Ennek érdekében nélkülözhetetlen a minél fiatalabb gyermekkorban megkezdett egészségtudatos nevelés. Ebben a folyamatban a közoktatási intézmények fontos és társadalmi egyenlőtlenségeket is moderáló színterekké válhatnak. Az oktatási intézményeken átívelö kortársoktatás mint lehetséges pedagógiai módszer, jól alkalmazkodik a 21. századi fiatal generáció által igényelt újszerü tudásátadáshoz. A vonatkozó nemzetközi szakirodalomban évtizedek óta találunk kortársoktatással (peer education) foglalkozó egészségnevelési programokat, azonban az alkalmazott pedagógiai módszertan keretei, a megvalósítás folyamata, valamint a tudományos hatékonyságmérés hiányosságokat mutat (Lukács et al., 2018).

Jelen közlemény célkitüzése az, hogy bemutassa az EDUVITAL Nonprofit Egészségnevelési Társaság és Alapítványból kinövő MTA-SE Egészségnevelés Kortárs-Oktatással Kutatócsoportot, a Tanuld, Tanítsd, Tudd (TANTUdSZ) programot. A cikk leírja a projekt létrejöttének tudományos hátterét, céljait, valamint az oktatási és a tudományos kutatási program szerkezetét, különös tekintettel az egyes tudományterületek, egyetemek, valamint a felsőfokú és közoktatási szintek közötti együttmüködésekre.

A magyar társadalom jelenlegi egészségi állapota és távlati kilátásai korántsem mondhatóak felhőtlennek. Kopp Mária és Skrabski Árpád tanulmányai (Kopp et al., 2004; Kopp et al., 2007) erre már korábban is felhívták a figyelmet. Az azóta tovább romló helyzet minden felelősen gondolkodó szakember számára azonnali, kötelező és hosszú távú feladatokat jelöl ki (Kopp et al., 2008; Kopp et al., 2011; Battams, 2016). Ennek felismerése is alapvetően hozzájárult az EDUVITAL kezdeményezés sikeréhez.

2012 eleje óta több hazai állami és egyházi fenntartású egyetem részvételével, az MTA Közoktatási Elnöki Bizottságának és a Tudományos Ismeretterjesztő Társaság támogatásával orvosok, pedagógusok, biológusok, pszichológusok, lelkészek, szociológusok, bioetikusok és egészségtudományi szakemberek életre hívták az EDUVITAL Nonprofit Egészségnevelési Társaságot (URL1), amely 2016-tól már Alapítvány formában is müködik.

A ténylegesen „alulról kezdeményezett” szervezet megalapítását különleges multidiszciplináris összefogás eredményezte, amelyhez hamarosan nagyon sok, nagyon sokféle hátterủ szakember csatlakozott.

$\mathrm{Az}$ alapítók és a résztvevők meggyőződése szerint az egészségtudatosság-egészségfejlesztés jelentős mértékben függ a korszerü, sokoldalú pszichoszociális, szociológiai és orvosbiológiai tudás széles körü hozzáférhetőségétől (Battams, 2016; Feith et al., 2016), valamint ezzel együtt a társadalom tagjainak személyes motivációjától is. Ezért közös feladat és felelősség, hogy a prevenciós, egészségnevelési feladatok sokkal markánsabb részt kapjanak. Ebből következik 
a pedagógiai, háziorvosi, iskola-, foglalkozás- és környezet-egészségügyi ellátás prevenciós szemléletủ átalakításának még hangsúlyosabbá tétele.

A proaktív interakció a szakember és egyén között minden korosztályban lényeges, de az egészséges életvitel jövőbeli mintázatának alakítása és az elért eredmények fenntarthatósága szempontjából különös figyelmet érdemel a jövő nemzedék, a gyermekek és a fiatal korosztály.

\section{AZ EDUVITAL MOZGALOM CÉLJA ÉS TEVÉKENYSÉGE}

Az egyre szélesebb körben ismert EDUVITAL mozgalom célja, hogy komplex, átfogó és a gyakorlati munkában, tanácsadásban jól használható, felelősségteljes információkat és alkalmazható pedagógiai technikákat dolgozzon ki és terjesszen az egészségnevelés/fejlesztés területén.

Az EDUVITAL tevékenysége kiterjed a tudományosságon alapuló, alapvető orvosbiológiai, epigenetikai, táplálkozásbiológiai, mozgási, mentális és fizikai, higiéniai, szenvedélybetegségekre vonatkozó, pszichológiai, esztétikai és szociológiai ismeretekre. A célcsoport, az X, Y és alfa generáció digitális motiváltsága miatt az írott formák mellett a multimédiás és internetes (például: webinarok, honlapok, Facebook), mobiltelefonon is elérhető oktatási anyagok létrehozására, optimalizálására és széles körü terjesztésére van szükség. A jelenkori korszerütlen hazai oktatáspolitika egyik súlyos és a magyar társadalom jövőjére tragikusan ható hiányosságának tartjuk a túlzsúfolt, lexikális tudásra alapozó közoktatási koncepcióban az egészségnevelés és a primer prevenciós szemlélet markáns hiányát (Kopp et al., 2007; Kopp et al., 2011). Központi oktatáspolitikai kérdésnek tartjuk, és minden tevékenységi formában aktívan teszünk azért, hogy kiemelt szerepet kapjanak az alap- és középszintü oktatásban a lelki-testi egészség, a mentálhigiénia, pszichoszomatikus kórképek kérdései, a családi és a bioetika legfőbb elemei is. Ennek alapján az EDUVITAL állandó nemzetközi kitekintéssel folyamatosan nyilvános szakmai, interdiszciplináris dialógust kezdeményez az orvosi, viselkedésgenetikai, pszichológiai és szociológiai tudományok fejlődésével kapcsolatos dilemmákról, a hagyományos egészségnevelést és orvoslást ebben a keretrendszerben megújítani kívánó szakmai kezdeményezésekről.

\section{AZ EDUVITAL EDDIGI LEGNAGYOBB VÁLLALKOZÁSA: \\ EGÉSZSÉGNEVELÉS KORTÁRSOKTATÁSSAL - TANULJ, TANITTSD, TUDD (TANTUDSZ)}

Az EDUVITAL elnyerte az MTA által 2015-ben, majd 2016-ban meghirdetett egy-, illetve négyéves Szakmódszertani (Tantárgyfejlesztési) kutatási pályázatot (MTA Tantárgypedagógiai Kutatási Pályázat). Ez a projekt egy kölcsönös felelősségtudatra építő, innovatív iskolai egészségnevelési program. 
A szakirodalom tényadatai (Kopp et al., 2011; Battams, 2016) és a részt vevő kutatók eddigi saját tapasztalatai (Feith et al., 2016) egyértelmủen arra utalnak, hogy a kortársoktatás és annak lehetséges továbbfejlesztése mint pedagógiai módszer kiemelt és bizonyíthatóan hatékonyabb lehetőséget nyújt a 21. századi fiatalabb generációk által igényelt és az egymás közötti, újszerü interaktív és multidiszciplináris tudásátadáshoz.

A három óvodában, kilenc közép- és általános iskola (hatodikosoktól kezdve tizenkettedikesekig) és negyvennégy, közoktatásban részt vevő pedagógus bevonásával bonyolított egészségnevelési-pedagógiai kutatási munkában két egyetemi kar, a Semmelweis Egyetem Egészségtudományi Karának és az Eötvös Loránd Tudományegyetem Tanító- és Óvóképző Karának oktatói, tanárai egymás tudását kiegészítő módon közösen vesznek részt. A két egyetem pedagógus-, illetve egészségügyi szakember képzéseiben részt vevő hallgatói közös elméleti képzésben, majd a kiscsoportban történő felkészülést követően valódi területi gyakorlaton (óvodai és iskolai közösségekben) dolgoznak együtt, szakmai és baráti kapcsolatokat alakítva ki, egymásra hatva és motivációikat megosztva egymással, ami nélkülözhetetlen a korszerủ egészségfejlesztési munkában. Ez a találkozás a felsőoktatási környezetben remélhetően előrevetíti a különböző hivatású szakemberek közötti későbbi életközösségeinek, feladatra koncentráló kooperációinak, sikerességének lehetőségét.

A TANTUdSZ-projekt új pedagógiai innovációkkal olyan hallgatók képzését dolgozza ki, akik az elsajátított egészségfejlesztési és egészségpedagógiai ismeretek, készségek és képességek birtokában alkalmasak óvodások és közoktatásban tanuló diákok körében kortársoktatói feladatok ellátására. Emellett a képzési modell része az is, hogy pedagógus, illetve egészségtudományi képzésben részt vevő felsőoktatási hallgatókkal együtt középiskolai tanulókat készítsenek fel és irányítsanak - folyamatos szakmai kontroll mellett - óvodás, általános iskolai és középiskolás (3-20 éves) gyermekek, tanulók körében végzendő, korosztály-specifikus és innovatív egészségfejlesztő tevékenységekre. A kortárs programok az egészséges táplálkozáshoz és mozgáshoz, a megfelelő higiénés magatartáshoz (Feith et al., 2018a; Lehotsky et al., 2018), elsősegélynyújtáshoz, valamint a lelki egészséghez kapcsolódó ismeretek és attitüdök fejlesztési területeihez kapcsolódnak.

Az elmúlt két évben a kísérleti programban két hazai és egy marosvásárhelyi egyetem (benne 119 pedagógus- és egészségtudományi képzés kortársoktató hallgató), három óvoda, hét alap- és középfokú oktatási intézmény (bennük huszonnégy középiskolai kortársoktató) vett részt. Megközelítőleg 1600 óvodás, általános és középiskolás diák részére történt kortársoktatás egészségnevelési program. A program során a résztvevők kézhigiéniai, folyadékfogyasztási és újraélesztési képzésére került sor kortársoktatási módszerrel. A TANTUdSZ-tematika hamarosan kiegészül a drog- és internetaddikciókra irányuló prevenciós, valamint stresszoldási és testmozgás projektekkel. 
A TANTUdSZ-program kvantitatív (kérdőíves felmérések, reflexiós naplók), kvalitatív (fókuszcsoportos beszélgetések), valamint fizikai kutatási módszerekkel (például kézszkennelési mérések a kézhigiéniai programokban) egyaránt teszteli a kísérleti oktatási program hatékonyságát, a benne részt vevők elégedettségét a felsőoktatási képzési szinttől kezdve a célpopuláció részére tartott oktatási programokig bezárólag, folyamatosan korrigálva az oktatási folyamat egészét (Kolosai et al., 2018a; Feith et al., 2018a).

Eredményeink szerint a kortársoktatás hatékony a tudásátadás, egészségmagatartás, attitüdváltozás dimenziók tekintetében, emellett a gyermekek számára vonzó pedagógiai módszeren alapul (Kolosai et al., 2018b). A programban részt vevő kortársoktató hallgatók folyamatos tutori segítség mellett valódi gyakorlati tudásra tesznek szert, növekszik a kooperációs képességük, a különböző tudományterületekről érkező hallgatókkal történő együttmüködési képességük, a teammunkában, önállóan történő hatékony és kreatív munkavégzésük, a probléma- és konfliktusmegoldási képességük, a felelősségvállalási szintjük. Ugyanakkor nehézséget okoz a nemzetközi trendeknek nem megfelelő hazai merev, valamint vertikálisan és horizontálisan is szükségtelenül élesen elkülönülő felsőoktatási és közoktatási rendszerbe beilleszteni egy korszerü, kortársoktatáson alapuló interaktív programot, de tapasztalataink szerint alapos előkészítéssel és koncepciózus tervezéssel megoldható.

Az EDUVITAL tevékenysége és a TANTUdSZ-pályázat által vállalt kutatómunka tehát egy nemrég formálódó egészségnevelési, illetve pedagógiai tudományos mühely közötti organikus összekapcsolódáson alapul.

A tudományos programban megvalósított kvantitatív, kvalitatív, valamint fizikai kutatási módszerekkel egyaránt tesztelt kísérleti oktatási és nevelési kezdeményezés hatékonyságának első eredményei a tudásszint, egészségmagatartás, attitűdváltozás dimenziók tekintetében válnak mérhetővé. A pályázatban részt vevő tutorok fókuszcsoportos felmérései és a felsőoktatási hallgatók reflexiós naplóinak célzott elemzése időben és mélységében is kiterjeszti a kutatás eredményeinek, illetve esetenkénti sikertelenségének értelmezési lehetőségeit, a kortársoktatók önreflexiós fejlődését és a kortársoktatás pedagógiai intervenciót körülölelő pozitív változásait, de nehézségeit is. Az eredményeink szerint ugyanez a hatékonyságnövelés érhető tetten a középiskolás és hallgatói kortársoktatók, illetve a tanártutorok felelősségtudatának fokozásában, illetve tudásátadás-elsajátítási motivációiban is. Mindezek túllépnek, a hazai egészségfejlesztési programokban egyébként döntően jelen levő ,frontális” oktatási megrögzöttségek sémáin. Így az interaktív kooperativitás emlékezetes közösségi élményét is nyújtják a gyakorlati tudás megszerzésében és a társadalmi (egészség)kultúra szintjének emelésében, alkalmat és kipróbálási lehetőséget nyújtva újszerủ (Kolosai et al., 2018a; Feith et al., 2018b) és konstruktív kortársoktatási megoldások innovációjára és fokozatos adaptálására. 
Ilyen például az az egyik módszertani innovációban kialakult megoldás, amikor a gyerekek kis csoportokban, megfelelő tutorális és hallgatói, valamint középiskolai kortársoktatói előkészítéssel és tutori kontrollal, mintegy „körkörösen”, egyben kölcsönösen egymást tanítják (Kolosai et al., 2018b). A többszörös és reciprok szerepvállalás az azonos életkorú kiscsoportokban a szó legszorosabb, szó szerinti értelmében vett kortársképzést jelent.

A konkrét kísérleti modellek (például: kézhigiénia, folyadékfogyasztás) releváns adattömegének eddigi értékelése, a folyamatban levők (például: újraélesztési programok) és egyéb gyakorlati egészségtudatos cselekvési formák bevezetése a kortársoktatás gyakorlatában számos jövőbeli, a neveléstudomány számára is hasznosítható eredményt ígér.

A kutatás a Magyar Tudományos Akadémia támogatásával, a Tantárgy-pedagógiai Kutatási Program keretében valósult meg.

\section{SZÉLES SPEKTRUMÚ SZAKEMBERGÁRDA EGYÜTTMÜKÖDÉSE AZ EGÉSZSÉGNEVELÉS FOLYAMATÁBAN}

Közismert és többszörösen bizonyított tény, hogy az epigenetikai hatások sokfélesége (táplálkozás, mozgás, dohányzás, alvásmennyiség, stressz, pszichoszociális, családi, környezeti-közösségi ingerek) és ezek együttese számos tudatosan befolyásolható elemet tartalmaz.

Ennek megfelelően a tudatos döntéseinken alapuló életmód és annak befolyásolható változtatása, komplex mentális epigenetikai spektrumot jelent, ami sokszínű szakmai összefogást és átgondolt, szakmailag megalapozott koordinációt kíván szakemberektől.

\section{IRODALOM}

Battams, S. (2016): Editorial: Public Mental Health Policy, Mental Health Promotion, and Interventions Which Focus on the Social Determinants of Mental Health. Frontiers of Public Health, 26, 285. DOI:10.3389/fpubh.2016.00285, https://www.ncbi.nlm.nih.gov/pmc/articles/ PMC5183633/

Falus A. (szerk.) (2016): Zene és egészség. Budapest: Kossuth Kiadó

Falus A. - Melicher D. (szerk.) (2015): Sokszinü egészségtudatosság. Értsd, Csináld, Szeresd. (UDUVITAL Müvek) Budapest: SpringMed Kiadó, http://mek.niif.hu/15900/15974/15974.pdf

Feith H. J. - Lehotsky Á. - Lukács A. et al. (2018a): Methodological Approach to Follow the Effectiveness of a Hand Hygiene Peer Education Training Programme at Hungarian Schools. Developments in Health Sciences, 1, 2, 39-43. DOI: 10.1556/2066.2.2018.13, https://akademiai. com/doi/full/10.1556/2066.2.2018.13

Feith H. J. - Lehotsky Á. - Füzi Á. R. et al. (2018b): Egy iskolai kézhigiénés egészségnevelési program hatásvizsgálatának tanulságai - az első pilot eredmények. Interdiszciplináris Magyar 
Egészségügy, 17, 18-23._http://www.eduvital.net/files/2018/beszamolo/IME\%2020171101\%20 Feith\%20et\%20al.pdf

Feith H. J. - Melicher D. - Máthé G. et al. (2016): Tapasztalatok és motiváltság: magyar középiskolások véleménye az egészségvédő programokról. Orvosi Hetilap, 157, 65-69. DOI: 10.1556/650.2015.30338, http://real.mtak.hu/35973/

Gilbert, J. H. V. - Yan, J. - Hoffman, S. J. (2010): Framework for Action on Interprofessional Education and Collaborative Practice. Geneva: WHO, http://www.who.int/hrh/resources/ framework_action/en/

Kolosai N. - Darvay S. - Füzi A. R. et al. (2018a): A kortársoktatás elméleti és gyakorlati aspektusai - A „Tanulj, tanítsd, tudd!” program tapasztalatai. Új Pedagógiai Szemle, 68, 7-8, 20-50. http://folyoiratok.ofi.hu/uj-pedagogiai-szemle/a-kortarsoktatas-elmeleti-es-gyakorlati-aspektusai-a-tanulj-tanitsd-tudd

Kolosai N. - Darvay S. - Krekó I. et al. (2018b): A kortársoktatás kutatása 3. Kortársoktatás a gyermekek és a felnőttek perspektívájából. Tanitó, 56, 9-13.

Kopp M. - Székely A. - Skrabski Á. (2004): Vallásosság és egészség az átalakuló társadalomban. Mentálhigiéné és Pszichoszomatika, 5, 103-125. http://real.mtak.hu/58483/1/mental.5.2004.2.1.pdf

Kopp M. S. - Skrabski Á. - Székely A. et al. (2007): Chronic Stress and Social Changes: Socioeconomic Determination of Chronic Stress. Annals of the New York Academy of Sciences, 1113, 325-338. DOI: 10.1196/annals.1391.006, https://www.academia.edu/14021518/Chronic_Stress_ and_Social_Changes_Socioeconomic_Determination_of_Chronic_Stress

Kopp M. S. - Stauder A. - Purebl G. et al. (2008): Work Stress and Mental Health in a Changing Society. European Journal of Public Health, 18, 238-444. DOI: 10.1093/eurpub/ckm077, https://academic.oup.com/eurpub/article/18/3/238/517936

Kopp M. S. - Skrabski A. - László K. D. et al. (2011): Gender Patterns of Socioeconomic Differences in Premature Mortality: Follow-up of the Hungarian Epidemiological Panel. International Journal of Behavioral Medicine, 18, 22-34. DOI: 10.1007/s12529-010-9126-5, https://bit. ly/31EJaeb

Lehotsky Á. - Falus A. - Lukács Á. et al. (2018): Kortárs egészségfejlesztési programok közvetlen hatása alsó tagozatos gyermekek kézhigiénés tudására és megfelelő kézmosási technikájára. Orvosi Hetilap, 159, 12, 485-490. DOI: 10.1556/650.2018.31031, http://real.mtak.hu/78967/

Lukács Á. - Darvay S. - Soósné Kiss Zs. et al. (2018): Kortárs egészségfejlesztési programok gyermekek és fiatalok körében a hazai és a nemzetközi szakirodalom tükrében: Szisztematikus áttekintés. Egészségfejlesztés, 59, 6-24. DOI: 10.24365/ef.v59i1.215, http://folyoirat.nefi. hu/index.php?journal=Egeszsegfejlesztes\&page $=$ article \&op $=$ view\&path $\% 5 \mathrm{~B} \% 5 \mathrm{D}=215 \&$ pat$\mathrm{h} \% 5 \mathrm{~B} \% 5 \mathrm{D}=\mathrm{pdf}$

Székely Cs. I. (2015): Zene és egészségnevelés. Új utak a zene megközelitéséhez. Módszertani segédlet pedagógusoknak interaktiv zenés foglalkozások szervezéséhez. (EDUVITAL Müvek 2) Budapest: EDUVITAL, http://www.eduvital.net/index.php/hu/eduvital-muvek/zene-es-egeszsegneveles

URL1: www.eduvital.net

URL1. http://www.eduvital.net/index.php/hu/tantudsz/ismerteto 